\title{
ANALIZA CALITĂȚII POTENȚIALULUI UMAN DIN PERSPECTIVA INSERȚIEI PE PIATTA MUNCII
}

\author{
Nicoleta ONOFREI ${ }^{\odot}$, cercetător științific, \\ Centrul de Cercetări Demografice al INCE, Republica Moldova
}

DOI: https://doi.org/10.36004/nier.cdr.2019.14-22

JEL Classification: J24, J44, R23.

Acest articol urmărește studierea posibilităților de creare a pieței muncii autohtone competitive prin efectuarea unei analize comparative a nivelului de educație a populației în vârstă aptă de muncă utilizând rezultatele Recensământului populației 2004 și ale Recensământului populației și al locuințelor 2014 privind repartiția populației după nivele de instruire, pe grupe de vârstă, care continuă studiile, rata de ocupare și rata șomajului pe nivele de instruire. Analiza comparativă dintre mun. Chișinău și Republica Moldova a oferit o perspectivă mai amplă a situației privind calitatea profesională a pieței muncii precum și posibilități de îmbunătățire a acesteia. Analiza nivelului de ocupare a populației aptă de muncă a permis de a constata faptul că rata de ocupare se află într-o relație directă cu nivelul de educație. Cuantumul cel mai înalt de ocupare în perioada 2016-2018 a fost observat la persoanele cu studii superioare și secundar profesionale. Totodată, rata de ocupare este mai mare în țară decât în mun. Chișinău pentru nivelele de instruire gimnazial, liceal și mediu de specialitate, pe când în mun. Chișinău rata de ocupare este mai mare pentru nivelele secundar profesional şi superior. In condițiile actuale urmează de a revizui măsurile orientate către încurajarea și asigurarea accesului la învățământ în zonele rurale, crearea unor programe speciale de învățământ care să permită învățarea pe tot parcursul vieții și recalificarea persoanelor, crearea unor locuri de muncă decente pentru antrenarea specialiștilor tineri și asigurarea corespunderii cererii și ofertei a potențialului uman.

Cuvinte-cheie: educație, capital uman, șomaj, piața muncii, Republica Moldova.

This article aims to study the possibilities of creating the competitive domestic labor market by performing a comparative analysis of the level of education of the working age population using the results of the 2004 Census of population and of the 2014 Population and Housing Census on the distribution of population by education levels, age groups, population that continue education, employment rate and unemployment rate by education levels. The comparative analysis between the municipality of Chisinau and the Republic of Moldova offered a broader perspective of the situation regarding the professional quality of labor market as well as possibilities for its improvement. The analysis of the employment level of the working population enabled us to find that the employment rate is in direct relation with the level of education. The highest amount of employment in the period 2016-2018 was observed for persons with higher and secondary vocational education. At the same time, the employment rate is higher in the country than in Chisinau municipality for the levels of high school and specialized education, while in Chisinau the employment rate is higher for the secondary and higher professional levels. In these circumstances, we propose to revise the measures aimed at encouraging and ensuring access to education in rural areas, the creation of special education programs that will allow lifelong learning and retraining, the creation of decent jobs for young specialists and ensuring matching the demand and supply of the human potential.

Key words: education, human capital, unemployment, labor market, Republic of Moldova.

Republica Moldova se confruntă cu probleme serioase privind dinamica populației și calitatea formării capitalului uman. Conform ultimelor date furnizate de BNS, în Republica

\footnotetext{
${ }^{\circledR}$ Nicoleta Onofrei, onofreinicoleta.94@gmail.com
} 
Moldova continuă scăderea numărului populației, în anul 2019 înregistrându-se 2,68 mil. persoane, fiind în descreștere cu cca 190 mii persoane comparativ cu anul 2014. Această descreștere drastică este cauzată în cea mai mare parte de migrația netă negativă, care a crescut de la 24,6 mii persoane în anul 2014 la 48,6 mii persoane în 2018. De asemenea, populaţia Republicii Moldova trece printrun proces de îmbătrânire foarte rapid. Coeficientul de îmbătrânire a populației a crescut de la 14,4\% în anul 2010 la 17,7\% în anul 2017, în mun. Chișinău acest indicator a înregistrat cuantumuri mai mici decât pe țară- 16,5\% în anul 2017 și $11,8 \%$ în anul 2010. La nivel global, Organizația Națiunilor Unite a comunicat că anul acesta pentru prima oară numărul persoanelor cu vârsta $65+$, care a atins 705 mil. persoane, a depășit numărul copiilor cu vârsta cuprinsă între 0-4 ani cu cca 25 mil. Conform prognozelor ONU, către anul 2050 numărul persoanelor cu vârsta $65+$ va crește cu cca 16\%, fiind de două ori mai mare decât numărul copiilor până la 5 ani [12]. În Republica Moldova în anul 2010, la 1000 de persoane în vârstă aptă de muncă reveneau 267 de pensionari și această cifră continuă să crească. Prognoza pentru anul 2050 este de aproximativ 730-790 pensionari la 1000 de persoane în vârstă aptă de muncă [1]. Având în vedere aceste procese demografice, care duc la schimbarea stucturii pe vârste a populației, deducem că povara socială devine tot mai mare pentru persoanele angajate care contribuie la fondul de pensii.

Efectele negative sunt observate și la nivelul sistemului educațional: insuficiența cadrelor didactice, scăderea constantă a numărului de elevi și studenți înrolați în învățământ, dar și neconcordanța dintre oferta educațională și cerințele pe piața muncii [5] sunt doar câteva dintre problemele care semnalează necesitatea unor reforme pe acest palier. Sistemul educațional este provocat să pregătească specialiști care să se poată încadra pe piața muncii, dar și să încurajeze învățarea pe tot parcursul vieții și să ofere posibilități de recalificare pentru a putea racorda oferta cu cererea pe piața muncii.

În Strategia Naţională de Dezvoltare “Moldova 2030”, printre obiectivele de dezvoltare durabilă sunt menționate: garantarea educației de calitate pentru toți, promovarea oportunităților de învățare pe tot parcursul vieții și asigurarea unui sistem de protecție socială solid și incluziv [7]. Accesul la educație de calitate pentru toți este o prioritate și pentru dezvoltarea comunității globale, fiind asumat de către țările lidere în strategia de dezvoltare în anul 2015 [11]. În scopul atingerii acestor obiective este necesară adoptarea unor politici bine ajustate realităților sociale și economice din țară în baza studiilor și cercetărilor aprofundate în acest domeniu.

Având scopul de a studia posibilităţi de creare a pieței muncii autohtone competitive s-a efectuat analiza comparativă a nivelului de educație a populației în vârstă aptă de muncă utilizând rezultatele Recensământului populației 2004 și a Recensământului Populației și al Locuințelor 2014 (în continuare RPL 2014) [6], ceea ce ar permite de a concluziona asupra calității profesionale a capitalului uman antrenat pe piața muncii. Totodată, analiza comparativă a domeniului în cauză din mun. Chișinău și în mediu în Republica Moldova oferă posibilitatea vizibilității mai ample a situației privind calitatea profesională a pieței muncii și posibilități de îmbunătățire a acesteia prin creșterea nivelului de educație al populației aptă de muncă.

Analizând datele Recensământului din anul 2004, constatăm că în mediu în Republica Moldova cea mai mare pondere a persoanelor cu studii universitare s-a înregistrat în categoriile de vârstă de 25-29 de ani și 55-59 ani - cca 17\%. În categoriile de vârstă cuprinse între 30-54 ani ponderea persoanelor cu studii superioare este aproximativ aceeași, menținându-se la un nivel de cca 13\% și coborând spre aproximativ 10\% și mai puțin în intervalul 20-24 ani în care tinerii încă sunt în formare, și începând cu vârsta de 65 ani. În mun. Chișinău, ponderea persoanelor care au atins nivelul de studii universitar este mai mare comparativ cu totalul pe republică, iar repartiția acestora pe categorii de vârstă este diferită. Astfel, cea mai mare pondere a persoanelor cu studii superioare se înregistrează în categoria 25-29 ani (cca 39\%), urmată de categoriile 30-34 și 65-69 ani cu aproximativ 32\%. În categoriile de vârstă din intervalul 35-64 ani ponderea se menține la nivelul de 30\%. De asemenea, diferența persistă și pentru grupul 20-24 de ani, în care se 
înregistrează cu aproximativ $8 \%$ mai mulți tineri cu studii superioare comparativ cu media pe țară (Fig. 1., lit. a. și b.). De asemenea, urmărind figurile menționate, observăm că în mun. Chișinău o pondere mai mare de persoane au cel puțin studii medii generale, comparativ cu media pe republică. Astfel, în grupele de vârstă dintre 20 și 59 de ani, cca 85\% din persoane au obținut cel puțin studii medii generale, în grupele 60-64 și 65-69 - între 70-75\%, iar în intervalele 15-19 și 70 și mai multaproximativ 50\%. Analiza pe întreg teritoriul țării arată că nivelul de instruire al persoanelor este mai scăzut: în categoriile de vârstă cuprinse între 30 și 49 de ani cca 70-75\% dintre persoane dețin studii medii generale, aproximativ 60\% în intervalele 20-29 și 50-59, și mai puţin de 40\% pentru celelalte categorii de vârstă care au avut posibilitatea să atingă un așa nivel de studii. Ponderea persoanelor în medie pe republică, care au cel puțin studii general obligatorii, este situată între 9598\% în intervalul 20-54 ani, aproximativ 90\% în categoriile 15-19 și 55-59 ani, 55\% în grupul 6569 și mai puțin de 30\% pentru persoanele care au 70 și mai mulți ani. Pe de altă parte, în mun. Chişinău mai mult de $98 \%$ din persoane cu vârsta între 15-59 ani au cel puțin studii generale obligatorii, între 90-95 \% în intervalul 60-69 ani și depășește 70\% în ultimul grup de vârstă 70 ani și mai mult. Totodată, gradul de analfabetism este mai mic în mun. Chișinău, înregistrându-se cca $2,5 \%$ în grupul de vârstă $70+$, comparativ cu $10 \%$ pe întreg cuprinsul țării în aceeași categorie și $2 \%$ în grupul 65-69 ani.

\section{a) Republica Moldova}

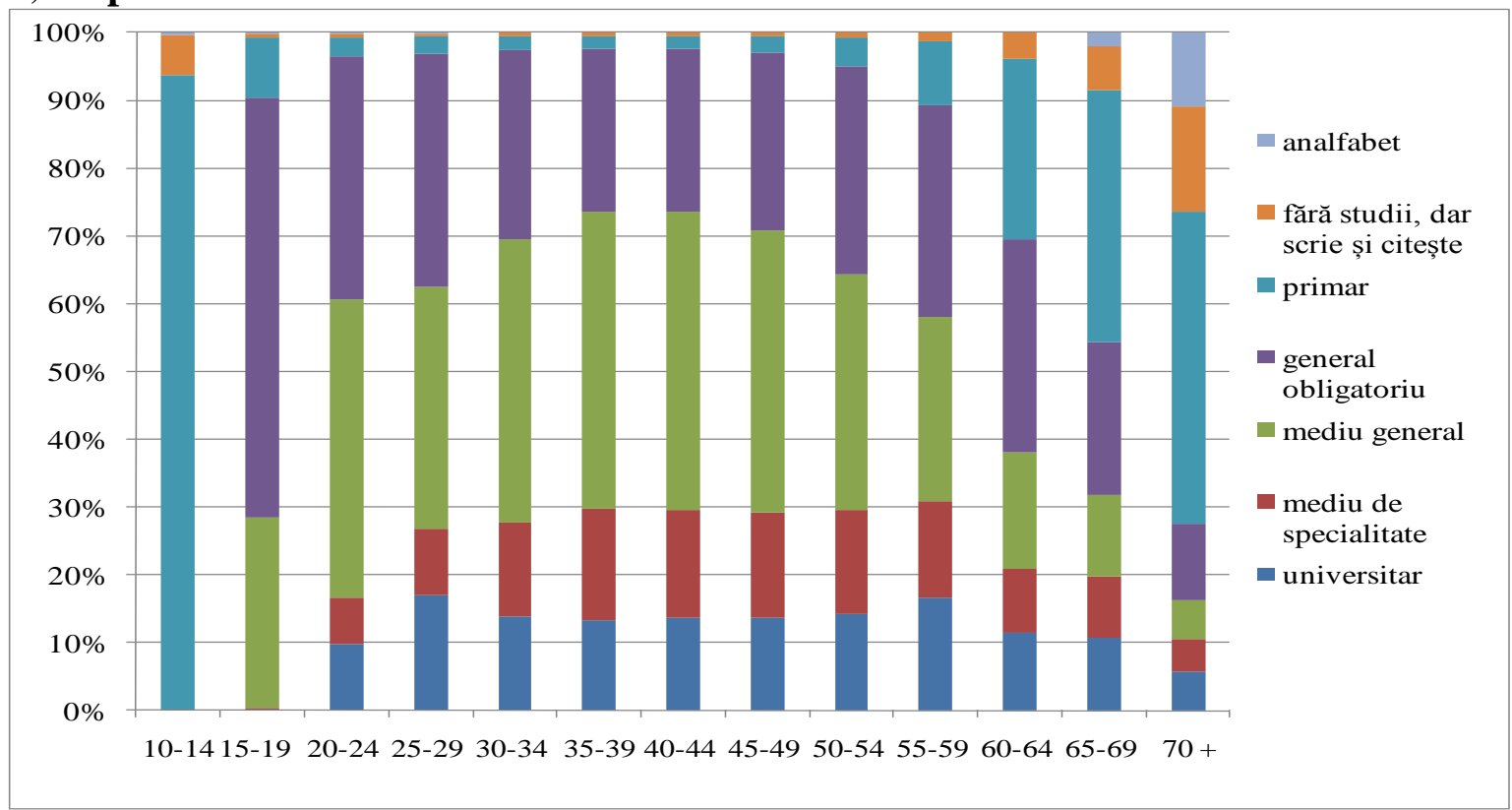

\section{b) Municipiul Chișinău}




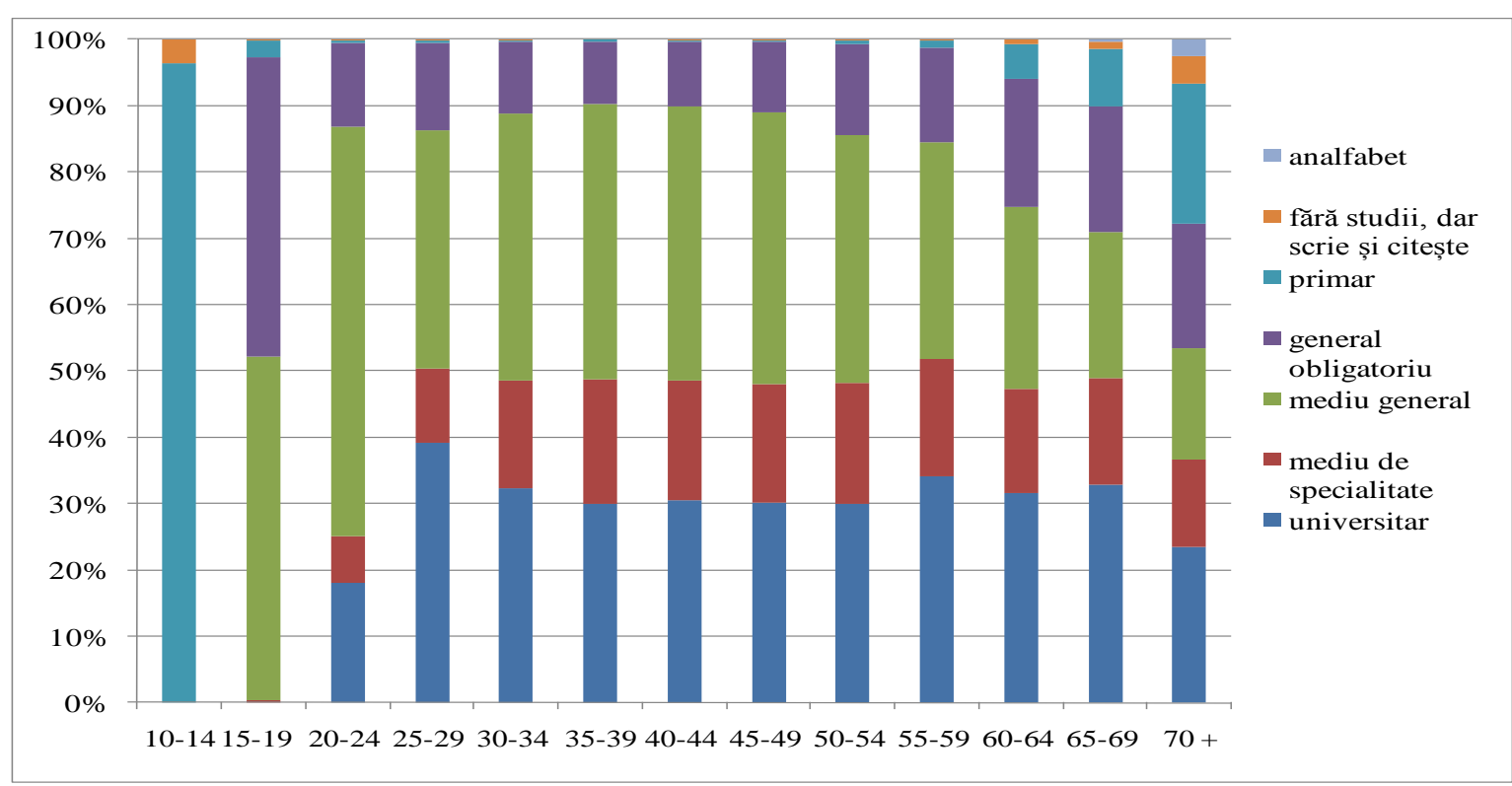

Figura 1. Populația în vârstă de 10 ani și peste după nivelul de instruire

Sursa: Date BNS, www.statistica.gov.md

Schimbarea metodologiei de prezentare a datelor privind populația (în RPL 2014 au fost incluse persoanele cu reședință obișnuită sau persoanele care locuiesc pe teritoriul Republicii Moldova pe o perioadă mai mare de 12 luni, indiferent de cetățenie), a influențat și asupra repartiției populației după nivelul de educație. Astfel, acest fapt nu permite de a efectua o analiză comparativă cu anul 2004 privind nivelul de instruire al populației în vârstă aptă de muncă pe categorii de vârstă. Reieșind din aceasta, evaluarea nivelului de educație a populației, utilizând datele RPL 2014, face referire la populaţia rezidentă care continuă studiile în intervalul 11- 24+ ani (Tabelul 1.). S-a urmărit această categorie de persoane pentru că, deși conform Codului Muncii al Republicii Moldova [3] copiii pot fi încadrați în câmpul muncii de la vârsta de 15 ani cu acordul părinţilor, în anumite condiții speciale, totuși problema privind munca copiilor de la vârste timpurii rămâne a fi actuală. Ultima cercetare statistică la această temă a fost realizată în anul 2009 Cercetare privind Activitățile Copiilor [4], care oferă indicatori cu privire la trei aspecte principale din viața copilului: școlarizarea, activitatea economică și activitățile gospodărești. Rezultatele studiului arată că cca $30,1 \%$ dintre copiii de 7-17 ani combină școala cu activitatea economică și activități casnice; $0,7 \%$ combină școala cu o activitate economică, iar 57,8\% din copii, pe lângă școală mai sunt ocupaţi și cu activitățile casnice și doar 7\% dintre copii sunt ocupați numai cu școala. Cota copiilor care sunt implicaţi doar numai în activităţi economice este sub $0,4 \%$, iar cota celor care sunt implicaţi doar numai în activităţi casnice este de 0,9\%. Există și o parte din copii care nu frecventează școala și nici nu sunt încadrați în activităţi economice sau casnice $(0,9 \%)$.

În urma cercetării nivelului de educaţie al populației rezidente (RPL 2014) care continuă studiile, pe grupe de vârstă pentru anul 2014 menționăm 3 tendințe principale:

- $\quad$ ponderea persoanelor care continuă studiile scade de la un interval de vârstă la următorul;

- $\quad$ in mun. Chișinău ponderea persoanelor care continuă studiile este mai mare decât media pe republică pentru toate categoriile de vârstă urmărite;

- în mediul urban numărul persoanelor la 1000 locuitori încadrate în învăţământ este în general mai mare decât cel din mediul rural, cu excepția primului grup de vârstă de 11-15 ani (Tabelul 1.).

Cea mai mare discrepanță se înregistrează pentru grupul de vârstă 24 și mai mulți ani: în mun. Chișinău, cca $36 \%$ din persoane continuă studiile comparativ cu $17 \%$ o pe tot cuprinsul țării. În primul grup de vârstă urmărit de 11-15 ani, cca 986 copii dintr-o mie continuă studiile în Republica 
Moldova, iar în mun. Chișinău - 992 persoane. În următoarele grupe de vârstă 16-18 ani și 19-23 ani sunt încadrați în învățământ 743\% și 419\%o în Republica Moldova, iar în mun. Chișinău $841 \%$ și respectiv $626 \%$.

Tabelul 1. Populația rezidentă care continuă studiile, pe grupe de vârstă, date relative la 1000 persoane

\begin{tabular}{|c|c|c|c|c|c|}
\hline & $\begin{array}{c}\text { Mediu de } \\
\text { reședință }\end{array}$ & $\mathbf{1 1 - 1 5}$ ani & $\mathbf{1 6 - 1 8}$ ani & $\mathbf{1 9 - 2 3}$ ani & $\mathbf{2 4 +}$ ani \\
\hline \multirow{3}{*}{ Republica Moldova } & Total & 986 & 743 & 419 & 17 \\
\cline { 2 - 6 } & Urban & 983 & 835 & 568 & 27 \\
\cline { 2 - 6 } & Rural & 987 & 698 & 338 & 11 \\
\hline \multirow{3}{*}{$\begin{array}{c}\text { Municipiul } \\
\text { Chișinău }\end{array}$} & Total & 992 & 841 & 626 & 36 \\
\cline { 2 - 6 } & Urban & 992 & 843 & 650 & 38 \\
\cline { 2 - 6 } & Rural & 994 & 830 & 456 & 24 \\
\hline
\end{tabular}

Sursa: Date BNS, www.statistica.gov.md

Ratele de frecventare a școlii sunt destul de mari pentru copiii din învățământul obligatoriu. Școlarizarea devine o problemă după cei 9 ani de învățământ, moment în care copiii au posibilitatea de a alege dacă să continue sau nu studiile. Mediul rural este mai defavorizat decât cel urban în acest aspect, înregistrându-se un număr mai mic de persoane în învățământ începând cu vârsta de 16-18 ani. Cauzele abandonului școlar ar putea fi atât situația financiară a familiei, cât și neperceperea vreunui beneficiu în şcolarizarea de mai departe sau plecarea la părinții aflați la muncă peste hotare. Studierea, inclusiv cercetarea sociologică a motivelor abandonului școlar, este importantă pentru înțelegerea și argumentarea politicilor eficiente de menținere a copiilor în școală și stimularea acestora de a obține performanțe în nivelele de educaţie superioare.

Nivelul educației este considerat un factor important și decisiv pentru bunăstarea vieții la nivel personal, dar și comunitar. Teoria capitalului uman pune în legătură directă educația cu ocuparea forței de muncă și mărimea salariului obținut [8]. Cu toate acestea, cercetările empirice demonstrează că această relație nu este respectată în toate cazurile, ocuparea forței de muncă fiind influențată de mai multe variabile economice. Un studiu realizat în China privind influența nivelului și a structurii educației asupra ocupării a demonstrat că dezvoltarea educației în China în prezent are efecte benefice asupra creșterii ratei de ocupare: creșterea proporției de angajați cu studii medii are efecte negative asupra ocupării, iar creșterea proporției de persoane cu studii superioare are efecte pozitive asupra acestui indicator [9]. Totuși, există și o altă parte "a monedei": numărul prea mare de persoane cu studii superioare poate genera "inflaţia academică". Prezența acestui fenomen într-o economie constă în dezechilibrul dintre cererea și oferta de pe piața muncii, sau depășirea ofertei forței de muncă față de cererea acesteia la un anumit nivel de educație. Acest fenomen contribuie la menținerea unei situații tensionate pe piața muncii, la creșterea concurenței atunci când numărul candidaților este mai mare decât locurile vacante de muncă ce corespund nivelului de studii al acestora sau la ocuparea unor posturi pentru care sunt supracalificați. Acest fenomen are repercursiuni negative asupra economiei în ansamblu, pentru că, pe de o parte, se consumă resurse atât materiale, cât și de timp pentru educație, iar pe de altă parte specialiștii nu au oportunități de a activa conform calificării. SUA este un exemplu elocvent în acest sens, deoarece structura industriei acestei țări nu este pregătită să absoarbă un număr atât de mare de absolvenți ai instituțiilor de învățământ superioare [10]. Din aceste considerente, este necesară studierea pentru fiecare economie în parte a impactului nivelului educației asupra pieței de muncă.

Analiza nivelului de ocupare a populației aptă de muncă în mun. Chișinău și în medie în Republica Moldova a permis de a constata faptul că indicatorul principal de evaluare a acesteia, rata de ocupare, se află într-o relație directă cu nivelul de educație (Tabelul 2.). Cuantumul cel mai înalt de ocupare în perioada 2016-2018 a fost observat la persoanele cu studii superioare și instruirii 
secundar profesionale atât în mun. Chișinău, cât și în medie în Republica Moldova. Acest fenomen poate fi influențat de faptul că angajatorii dau întâietate totuși candidaților cu studii superioare, chiar dacă sunt supracalificaţi pentru job-ul respectiv. Acest lucru dezavantajează în mod vădit pe cei care nu au un nivel atât de înalt de studii, servind drept stimulent pentru a urma studii superioare. Persoanele cu studii secundar profesionale au o rată de ocupare mai mare decât cele cu studii medii de specialitate, diferența fiind mai accentuată în mun. Chișinău, decât pe întreg teritoriul Republicii Moldova. În perioada analizată, rata de ocupare a fost mai mare în mediu pe țară decât în municipiul Chișinău pentru nivelele de instruire gimnazial (cu 4-9 p.p.), liceal (cu 1,62,6 p.p.) și mediu de specialitate (cu 2,5-5,6 p.p.), pe când în mun. Chișinău rata de ocupare este mai mare pentru nivelele secundar profesional (3,5-6,0 p.p.) și superior (2,7-4,0 p.p.). Acest fapt se explică prin posibilitățile mai favorabile și lărgite de a obține un anumit fel de studii, de instruiri profesionale, precum și de specificul domeniilor de activitate din capitală, care necesită un anumit nivel de studii. Totodată, în urma reformelor structurale ce au loc în perioada de tranziție la economia de piață, distrugerea infrastructurii sociale, apariția noilor forme de proprietate, în special a formei private, inclusiv și în domeniul educației (forma de studii prin contract), diferențierea socială a populației au contribuit la faptul că nu orice tânăr are posibilitatea de a plăti pentru studii, în timp ce o bună parte din persoanele din țară activează în sectorul agricol din motivul lipsei posibilității alternative de a fi ocupat în alt domeniu. $\mathrm{Cu}$ toate acestea, este necesar de menționat, către anul 2018, comparativ cu anii precedenți, rata de ocupare în mun. Chișinău a scăzut la toate nivelele de instruire, ceea ce semnalează un trend general de scădere a ratei de ocupare indiferent de calificarea persoanelor.

Tabelul 2. Rata de ocupare și evoluția acesteia pe nivele de instruire, \% /p.p.

\begin{tabular}{|c|c|c|c|c|c|c|c|}
\hline \multirow[b]{2}{*}{ Nivel de instruire } & \multirow[b]{2}{*}{ Regiune } & \multicolumn{2}{|c|}{2016} & \multicolumn{2}{|c|}{2017} & \multicolumn{2}{|c|}{2018} \\
\hline & & $\begin{array}{l}\text { Rata de } \\
\text { ocupare }\end{array}$ & $\begin{array}{c}\text { Comparație } \\
\text { cu anul } \\
\text { anterior }\end{array}$ & $\begin{array}{l}\text { Rata de } \\
\text { ocupare }\end{array}$ & $\begin{array}{c}\text { Comparație } \\
\text { cu anul } \\
\text { anterior }\end{array}$ & $\begin{array}{l}\text { Rata de } \\
\text { ocupare }\end{array}$ & $\begin{array}{c}\text { Comparație } \\
\text { cu anul } \\
\text { anterior }\end{array}$ \\
\hline \multirow{2}{*}{ Gimnazial } & Total & 31,5 & $+1,2$ & 31,3 & $-0,2$ & 35,0 & $+3,7$ \\
\hline & M. Chișinău & 27,5 & $-0,2$ & 25,4 & $-2,1$ & 25,6 & $+0,2$ \\
\hline \multirow{2}{*}{ Liceal } & Total & 38,2 & $+1,4$ & 37,3 & $-0,9$ & 38,1 & $+0,8$ \\
\hline & M. Chișinău & 36,7 & $-2,2$ & 34,7 & $-2,0$ & 35,9 & $+1,2$ \\
\hline \multirow{2}{*}{$\begin{array}{c}\text { Secundar } \\
\text { profesional }\end{array}$} & Total & 47,0 & $+0,1$ & 46,3 & $-0,7$ & 47,7 & $+1,4$ \\
\hline & M. Chișinău & 53,0 & $-1,8$ & 50,9 & $-2,1$ & 51,2 & $+0,3$ \\
\hline \multirow{2}{*}{$\begin{array}{c}\text { Mediu de } \\
\text { specialitate }\end{array}$} & Total & 44,6 & $-1,1$ & 47,7 & $+3,1$ & 42,9 & $-4,8$ \\
\hline & M. Chişinău & 42,0 & $-3,0$ & 42,3 & $-0,3$ & 42,7 & $+0,4$ \\
\hline \multirow{2}{*}{ Superior } & Total & 57,1 & $+0,1$ & 56,0 & $-1,1$ & 56,6 & $+0,6$ \\
\hline & M. Chișinău & 61,3 & $+0,5$ & 59,3 & $-2,0$ & 59,3 & 0 \\
\hline
\end{tabular}

Sursa: Date BNS, www.statistica.gov.md

Numărul populației ocupate din Republica Moldova a crescut în anul 2018 comparativ cu anul 2008 pentru persoanele cu studii superioare și gimnaziale. Atât în Republica Moldova cât și separat în municipiul Chișinău printre populația ocupată predomină persoanele cu studii superioare (303,1 mii persoane în 2018 sau s-a majorat cu 18,5\% și a constituit 24,2\% din populația ocupată) în Republica Moldova și în mun. Chișinău (153,7 mii persoane în 2018 sau s-a majorat cu 12,2\% și a constituit 48,2\% din populația ocupată) [2], (Fig. 2.). O pondere semnificativă a populației ocupate per total o constituie persoanele cu studii secundar profesionale $(22,9 \%$ pe republică și 16,1\% în municipiul Chișinău), gimnaziale (20,7\% pe republică și 6,3\% în municipiul Chișinău), liceale $(18,7 \%$ pe republică și $15,7 \%$ în municipiul Chișinău) și medii de specialitate $(12,9 \%$ pe republică și $13,7 \%$ în municipiul Chișinău), care împreună constituie 941,8 mii persoane pe republică, depășind prin urmare de 3 ori numărul persoanelor cu studii superioare și 165,3 mii persoane în municipiul Chișinău, depășind, respectiv, de 1,1 ori numărul persoanelor cu studii 
superioare. Caracteristica comparativă a populației ocupate după nivelul de instruire se reflectă în Fig. 2.

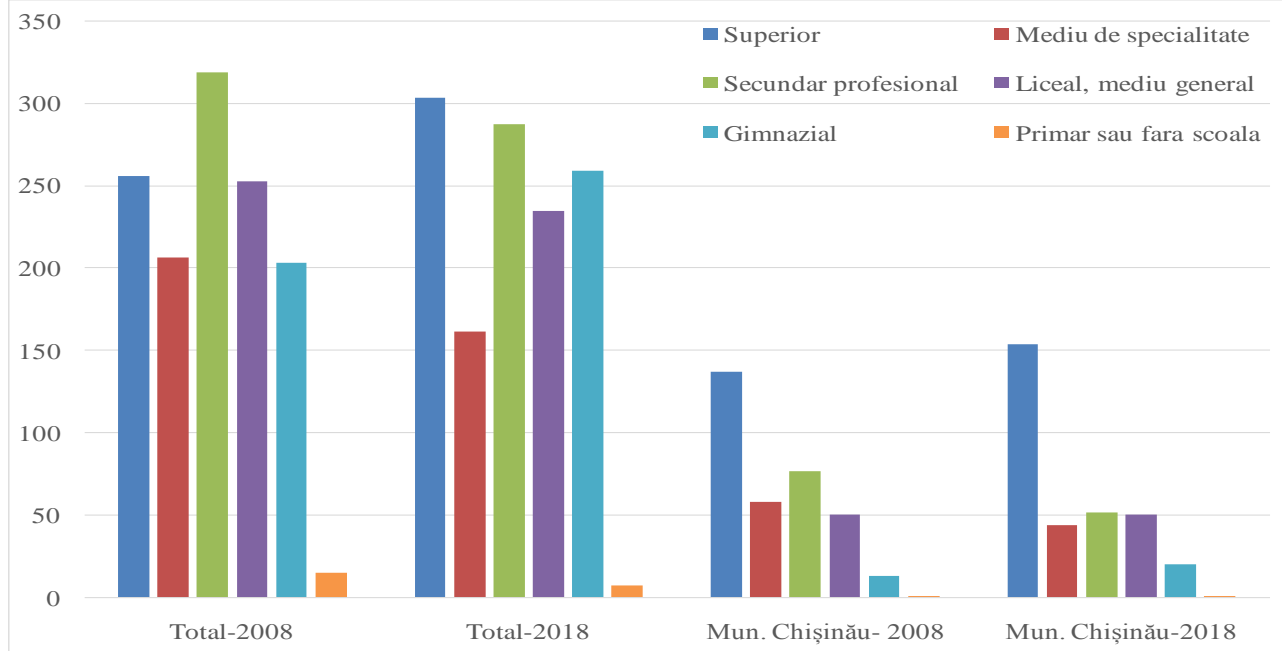

Figura 2. Populația ocupată de 15 ani și peste pe nivele de studii, mii persoane Sursa: Date BNS, www.statistica.gov.md

În perioada analizată, rata șomajului s-a micșorat atât la nivelul țării, cât și în mun. Chișinău pentru toate nivelele de instruire. Doar în cazul absolvenților cu studii medii de specialitate din mun. Chișinău s-a înregistrat o creștere a ratei șomajului cu 1,4 p.p. în 2018 față de 2016. Există o discrepanță între rata șomajului totală pe Republica Moldova și cea din mun. Chișinău, prima fiind mai mică pentru toate nivelele de instruire. Până la nivelul mediu de specialitate această diferență se menține la nivelul de cca $2 \%-3 \%$, fiind mult mai mică pentru nivelul superior $-0,5 \%$, datorită descreșterii ratei șomajului în mun. Chișinău pentru nivelul superior de instruire (Tabelul 3.).

Tabelul 3. Evoluția ratei de șomaj pe nivele de instruire

\begin{tabular}{|c|c|c|c|c|c|c|c|c|}
\hline \multirow[b]{2}{*}{$\begin{array}{c}\text { Nivel } \\
\text { de instruire }\end{array}$} & \multirow[b]{2}{*}{ Regiune } & \multicolumn{2}{|c|}{2016} & \multicolumn{2}{|c|}{2017} & \multicolumn{2}{|c|}{2018} & \multirow[b]{2}{*}{$\begin{array}{c}2018 \text { față } \\
\text { de } 2016, \\
\text { p.p. }\end{array}$} \\
\hline & & $\begin{array}{c}\text { Rata de } \\
\text { şomaj, } \\
\%\end{array}$ & $\begin{array}{c}\text { Comparație } \\
\text { cu anul } \\
\text { anterior, } \\
\text { p.p. }\end{array}$ & $\begin{array}{c}\text { Rata de } \\
\text { şomaj, } \\
\%\end{array}$ & $\begin{array}{c}\text { Comparatie } \\
\text { cu anul } \\
\text { anterior, } \\
\text { p.p. }\end{array}$ & $\begin{array}{c}\text { Rata de } \\
\text { șomaj, } \\
\%\end{array}$ & $\begin{array}{c}\text { Comparație } \\
\text { cu anul } \\
\text { anterior, } \\
\text { p.p. }\end{array}$ & \\
\hline \multirow{2}{*}{ Gimnazial } & Total & 4,5 & $-2,1$ & 4,3 & $-0,2$ & 2,8 & $-1,5$ & $-1,7$ \\
\hline & Mun. Chișinău & 9,2 & $-6,4$ & 9,6 & $+0,4$ & 7,4 & $-2,2$ & $-1,8$ \\
\hline \multirow{2}{*}{ Liceal } & Total & 4,1 & 0 & 4,0 & $-0,1$ & 2,7 & $-1,3$ & $-1,4$ \\
\hline & Mun. Chișinău & 6,7 & -1 & 6,0 & $-0,6$ & 5,7 & $-0,3$ & $-1,0$ \\
\hline \multirow{2}{*}{$\begin{array}{c}\text { Secundar } \\
\text { profesional }\end{array}$} & Total & 4,0 & $-0,8$ & 4,7 & $+0,7$ & 2,9 & $-1,8$ & $-1,1$ \\
\hline & Mun. Chișinău & 6,4 & $+0,1$ & 8,2 & $+1,8$ & 4,9 & $-3,3$ & $-1,5$ \\
\hline \multirow{2}{*}{$\begin{array}{l}\text { Mediu de } \\
\text { specialitate }\end{array}$} & Total & 3,5 & $-0,6$ & 3,7 & $+0,2$ & 3,4 & $-0,3$ & $-0,1$ \\
\hline & Mun. Chișinău & 5,3 & $-0,7$ & 6,2 & $+0,9$ & 6,7 & $+0,5$ & $+1,4$ \\
\hline \multirow{2}{*}{ Superior } & Total & 4,5 & $-0,3$ & 3,7 & $-0,8$ & 3,1 & $-0,6$ & $-1,4$ \\
\hline & Mun. Chișinău & 4,6 & -1 & 4,3 & $-0,3$ & 3,6 & $-0,7$ & $-1,0$ \\
\hline
\end{tabular}

Sursa: Date BNS, www.statistica.gov.md

În ultimii cinci ani fluxul migrațional peste hotare în căutarea unui loc de muncă a avut o tendință instabilă, fiind în descreștere în perioada 2014-2017, dar a crescut cu 10,8\% per total în Republica Moldova în anul 2018. În mun. Chișinău, dimpotrivă, creșterea fluxului migrațional a fost înregistrată începând cu 2016, iar în anul 2018 creșterea a constituit 22,7\% față de anul precedent. Schimbările au fost înregistrate și în nivelul de instruire a emigranților. Astfel, în anul 2014 ponderea cea mai mare a emigranților în căutarea unui loc de muncă în medie în Republica Moldova s-a înregistrat pentru emigranții cu studii secundar profesionale și gimnaziale $(26,6 \%$, 
respectiv 26,4\%), urmată de categoria emigranților cu studii liceale, medii generale $(23,6)$, medii de specialitate $(11,9)$ și superioare $(11,0 \%)$. În mun. Chișinău, în același an, emigranţii cu studii superioare au avut cea mai mare pondere- $32,2 \%$, continuând cu grupurile de emigranți cu studii incomplete (liceale, medii generale- 23,2\%; medii de specialitate 19,8\%; secundare profesionale16,7\% și gimnaziale- 8,1\%). In anul 2018 structura emigranţilor după nivele de instruire nu s-a modificat semnificativ, în medie pe țară cele mai mari ponderi de emigranți fiind cu un nivel de studii inferior, iar în capitală- invers, predomină ponderea emigranților cu un nivel mai înalt de studii (Tabelul 4.).

Tabelul 4. Structura populației plecate peste hotare în căutarea unui loc de muncă după nivelul de instruire, 2016-2018

\begin{tabular}{|c|c|c|c|c|c|c|c|c|c|c|}
\hline & \multicolumn{2}{|c|}{2014} & \multicolumn{2}{|c|}{2015} & \multicolumn{2}{|c|}{2016} & \multicolumn{2}{|c|}{2017} & \multicolumn{2}{|c|}{2018} \\
\hline & $\mathrm{RM}$ & $\begin{array}{l}\text { Mun. } \\
\text { Chișinău }\end{array}$ & $\mathrm{RM}$ & $\begin{array}{c}\text { Mun. } \\
\text { Chișinău }\end{array}$ & $\mathrm{RM}$ & $\begin{array}{c}\text { Mun. } \\
\text { Chișinău }\end{array}$ & $\mathrm{RM}$ & $\begin{array}{c}\text { Mun. } \\
\text { Chișinău }\end{array}$ & $\mathrm{RM}$ & $\begin{array}{l}\text { Mun. } \\
\text { Chișinău }\end{array}$ \\
\hline $\begin{array}{l}\text { Nivel de instruire - } \\
\text { total }\end{array}$ & 341,9 & 32,3 & 325,4 & 33,5 & 319,0 & 31,1 & 318,4 & 36,5 & 352,7 & 44,8 \\
\hline Superior & 37,7 & 10,4 & 42,9 & 12,3 & 42,4 & 10,1 & 46,6 & 12,6 & 47,5 & 15,2 \\
\hline $\begin{array}{c}\text { Mediu de } \\
\text { specialitate }\end{array}$ & 40,8 & 6,4 & 35,1 & 4,8 & 34,3 & 4,4 & 34,9 & 4,6 & 37,1 & 6,7 \\
\hline $\begin{array}{c}\text { Secundar } \\
\text { profesional }\end{array}$ & 90,9 & 5,4 & 84,6 & 5,4 & 76,4 & 5,6 & 79,5 & 6,9 & 90,9 & 7,5 \\
\hline $\begin{array}{l}\text { Liceal, mediu } \\
\text { general }\end{array}$ & 80,8 & 7,5 & 78,9 & 8,4 & 77,8 & 7,2 & 75,1 & 10,2 & 83,1 & 12,9 \\
\hline Gimnazial & 90,3 & 2,6 & 83,5 & 2,7 & 87,7 & 3,6 & 81,5 & 2,2 & 92,4 & 2,6 \\
\hline $\begin{array}{c}\text { Primar sau fara } \\
\text { scoala } \\
\end{array}$ & 1,4 & 0,0 & 0,5 & - & 0,3 & 0,1 & 0,8 & - & 1,8 & - \\
\hline $\begin{array}{c}\text { Nivel de instruire - } \\
\text { total }\end{array}$ & 100,0 & 100,0 & 100,0 & 100,0 & 100,0 & 100,0 & 100,0 & 100,0 & 100,0 & 100,0 \\
\hline Superior & 11,0 & 32,2 & 13,2 & 36,6 & 13,3 & 32,6 & 14,6 & 34,6 & 13,5 & 33,9 \\
\hline $\begin{array}{c}\text { Mediu de } \\
\text { specialitate }\end{array}$ & 11,9 & 19,8 & 10,8 & 14,3 & 10,7 & 14,2 & 11,0 & 12,6 & 10,5 & 14,9 \\
\hline $\begin{array}{c}\text { Secundar } \\
\text { profesional }\end{array}$ & 26,6 & 16,7 & 26,0 & 16,1 & 24,0 & 18,1 & 25,0 & 18,9 & 25,8 & 16,7 \\
\hline $\begin{array}{c}\text { Liceal, mediu } \\
\text { general }\end{array}$ & 23,6 & 23,2 & 24,2 & 25,0 & 24,4 & 23,2 & 23,6 & 27,9 & 23,6 & 28,7 \\
\hline Gimnazial & 26,4 & 8,1 & 25,7 & 8,0 & 27,5 & 11,6 & 25,6 & 6,0 & 26,2 & 5,8 \\
\hline $\begin{array}{c}\text { Primar sau fara } \\
\text { scoala }\end{array}$ & 0,5 & 0,0 & 0,1 & - & 0,1 & 0,3 & 0,2 & - & 0,4 & - \\
\hline
\end{tabular}

Sursa: Date BNS, www.statistica.gov.md

Analiza datelor privind nivelul educaţiei populației și a gradului de inserție pe piața muncii în total în Republica Moldova și separat în mun. Chișinău, datorită concentrării forței de muncă tinere în capitală, a arătat existența diferențelor atât în nivelul de educație a populației, cât și a nivelului de ocupare și specificul ocupării dintre capitală și media pe republică.

În concluzie conform rezultatelor cercetărilor, evidențiem principalele tendințe privind educația populației:

- scăderea ponderii persoanelor care continuă studiile de la un grup de vârstă la următorul;

- ponderea mai mare a persoanelor care continuă studiile în mun. Chișinău decât media pe republică pentru toate categoriile de vârstă urmărite;

- înregistrarea unui număr mai mare de persoane încadrate în învățământ în mediul urban decât în cel rural, cu excepția grupului de vârstă 11-15 ani.

Cea mai mare pondere a persoanelor cu studii superioare în mun. Chișinău se înregistrează pentru intervalul de vârstă 25-29 ani - 39\%, respectiv, în Republica Moldova - 17 \%. În mun. Chișinău predomină ponderea persoanelor cu studii medii generale și mai înaltă ( 85 \% în intervalul 
de vârstă 20-59 ani). În medie în Republica Moldova ponderea celor cu studii medii generale și mai înaltă în categoria de vârstă 30-49 ani a constituit $75 \%$.

Accesul mai ușor la studii pentru populația din capitală, dar și cerințele locurilor de muncă locale determină persoanele trecute de vârsta tânără să continue studiile și să se perfecționeze, ceea ce are un impact pozitiv asupra ratei de ocupare. Acest rezultat s-a reflectat în analiza nivelului de ocupare al populației aptă de muncă, care a permis de a constata faptul că rata de ocupare se află într-o relație directă cu nivelul de educație. Rata de ocupare în perioada 2016-2018 a fost mai mare la persoanele cu studii superioare și secundar profesionale, comparativ cu nivelele de studii inferioare, atât în mun. Chișinău, cât și în Republica Moldova. Acest indicator este mai mare în Republica Moldova decât în mun. Chișinău pentru persoanele cu studii gimnaziale, liceale și medii de specialitate, pe când în mun. Chișinău - pentru nivelele secundar profesional și cel superior.

În același timp, dacă în general în Republica Moldova predomină șomerii cu un nivel scăzut de educație, atunci în mun. Chișinău persistă problema șomerilor cu studii superioare.

Aceste fenomene de pe piaţa muncii au repercursiuni negative asupra dezvoltării socioeconomice nu doar a țării, dar și a mun. Chișinău. Persoanele șomere cu un nivel înalt de studii sunt puse în situația fie de a găsi un loc de muncă în altă localitate decât cea de baștină - migrația de muncă internă, sau să emigreze peste hotare în căutarea unui loc de muncă potrivit, inclusiv cu un salariu satisfăcător, tendință observată atât printre tineri, cât și la populația în vârstă aptă de muncă. Un risc sporit de exod al forței de muncă din țară va contribui la atenuarea competitivității pieței muncii naționale și locale și, în final, creșterea stabilă a economiei având în vedere că această piață constituie un element important al acesteia.

Creșterea nivelului de educație al populației este benefică dezvoltării țării, dar aceasta trebuie însoțită și de dezvoltarea socioeconomică durabilă care să asigure locurile de muncă corespunzătoare. Pe fundalul condițiilor actuale se propune perfecționarea politicilor și măsurilor în următoarele direcții:

- încurajarea și asigurarea accesului la învățământ în zonele rurale, defavorizate, crearea unor programe speciale de învățământ care să permită învățarea pe tot parcursul vieții și recalificarea persoanelor având în vedere progresul tehnologic;

- asigurarea locurilor de muncă decente pentru ocuparea cât mai deplină a tinerilor specialiști, absolvenţii diferitor nivele de educaţie, în special din zone de risc (lipsa infrastructurii socioeconomice, instituțiile educaţionale, obiectelor culturale etc.), având un potențial capabil de fructificat pentru dezvoltarea țării;

- elaborarea cercetărilor sociologice mai ample privind asigurarea corespunderii cererii și ofertei a potențialului uman la nivel de municipii, regiuni, raioane, având scopul de a perfecționa sistemul de pregătire profesională calitativă a specialiștilor pentru economia națională în funcție de cerințele actuale ale angajatorilor.

\section{Bibliografie}

1. Baskakov V.N. Sistemul de pensii al Republicii Moldova: expertiza actuarială. Centrul Independent Actuarial Informaţional $\quad-\quad$ Analitic, 2007. http://www.pension.md/eng/publications/ps/46.html.

2. Biroul Național de Statistică al Republicii Moldova (BNS). http://statbank.statistica.md/pxweb/pxweb/ro/30\%20Statistica\%20sociala/30\%20Statistica\%20socia la_03\%20FM_03\%20MUN_MUN010/MUN010900reg.px/table/tableViewLayout1/?rxid=2345 d98a-890b-4459-bb1f-9b565f99b3b9.

3. Codul Muncii al Republicii Moldova, Legea nr.154 din 28.03.2003. Monitorul Oficial al Republicii Moldova, 2003, nr. 159-162, art 548. Modificat: Legea nr.155 din 20.07.2017. Monitorul Oficial al Republicii Moldova, 2017, nr. 316-321, art 548. 
4. Organizația Internațională a Muncii și Biroul Național de Statistică, 2010. Munca copiilor în Republica Moldova: Rezultatele cercetării din 2009 vizând activităţile copiilor. Chişinău, Republica Moldova. http://statistica.gov.md/pageview.php?l=ro\&idc=350\&id=3117.

5. Otter T., Barbăroșie A. \& Gremalschi A. Educația și dezvoltarea umană: provocări curente și de perspectivă. Document de politici. PNUD Moldova, 2010.

6. Rezultatele Recensămîntului Populaţiei din 2004. Biroul Naţional de Statistică al Republicii Moldova. Biroul Naţional de Statistică al Republicii Moldova. http://statistica.gov.md/pageview.php?l=ro\&idc=295\&.

Rezultatele Recensământului Populației și al Locuințelor 2014 (RPL2014). Biroul Național de Statistică al Republicii Moldova. Biroul Național de Statistică al Republicii Moldova. http://statistica.gov.md/pageview.php?1=ro\&idc=479\&.

7. Strategia Națională de Dezvoltare "Moldova 2030". Monitorul Oficial al Republicii Moldova, 2018, nr. $\quad 159-162, \quad$ art 1161. https://gov.md/sites/default/files/document/attachments/intr40_12_0.pdf.

8. Becker G. S. Investment in human capital: A theoretical analysis. Journal of Political Economy, 1962, 70(5), p. 9-49.

9. Chen Z. \& Yongqiu W. The relationship between education and employment: A theoretical analysis and empirical test. Frontiers of Economics in China, 2007, 2(1), p. 187-211.

10. Gon Y. \& Mcmurtrey M. The impact of academic inflation on the labour market: if everyone will have a $\mathrm{PhD}$, who will be the custodian? International Journal of Electronic Finance, 2013, 7(3/4), p. 250-262. DOI: 10.1504/IJEF.2013.058605.

11. OECD. Education at a Glance: OECD Indicators. OECD Publishing, Paris, 2018. http://dx.doi.org/10.1787/eag-2018-en.

12. United Nations, Department of Economic and Social Affairs, Population Division. World Population Prospects 2019: Highlights (ST/ESA/SER.A/423).

https://population.un.org/wpp/Publications/Files/WPP2019_Highlights.pdf. 